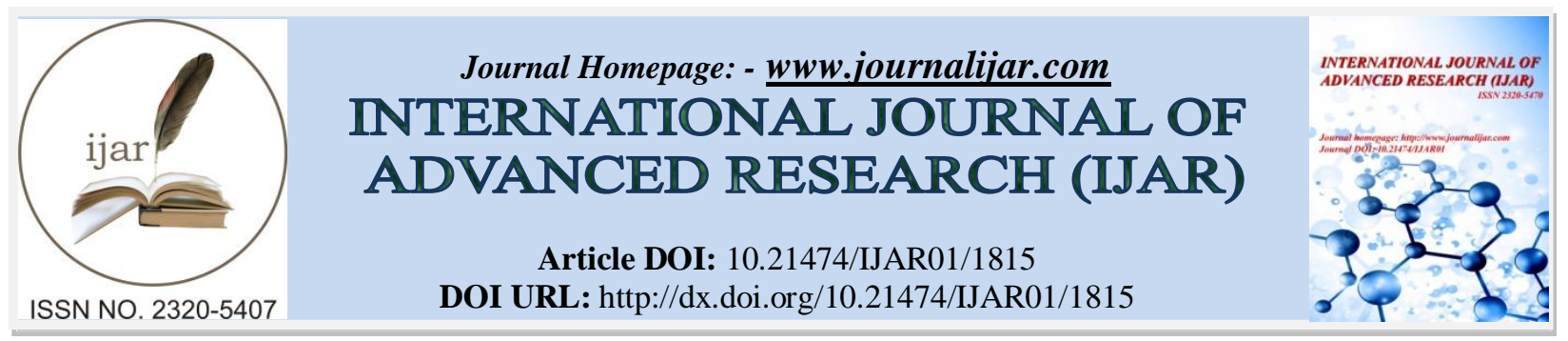

RESEARCH ARTICLE

\title{
IMPACT OF HEAVY METAL COPPER CHLORIDE ON FISH LABEO ROHITA
}

\author{
Dr. Alkesh I. Shah. \\ Associate Professor \& Head, Zoology Department, B. P. Baria Science Institute, Navsari - 396445, Gujarat, India.
}

\section{Manuscript Info}

Manuscript History

Received: 14 August 2016

Final Accepted: 22 September 2016

Published: October 2016

Key words:-

Copper chloride, Chromatography,

Histidine, Proline, Glycine, Alanine,

Methionine and Valine.

\begin{abstract}
The term 'water pollution', is generally applied to aquatic various types of contamination. Toxic metals from lead acid battery manufacturing, paint manufacturing, viscose rayon manufacturing, electroplating works, copper pickling, galvanizing and rubber processing, are some of the major industries which discharge effluents containing considerable amounts of heavy metals. The primary metals considered to be toxic are lead, arsenic, copper, cadmium, mercury, nickel. Some agricultural and forestry products also add many toxic pollutants to fresh water. These additions may be indirect. In the current study, the main aim is to access the effect of copper in fresh water edible fish Labeo rohita, also known as major carp. Copper has essentially been a beneficial element in human metabolism. A deficiency of copper gives rise to nutritional problems in infants. Copper imparts some undesirable taste to water and can be been detected in range from 1 to $5 \mathrm{ppm}$. Small amounts are not generally considered to be toxic, but very large doses may cause sickness, and in extreme cases may lead to liver damage. During the use of copper sulphate in a surface water supply for algal control, the levels have to be closely monitored and controlled. Copper in small amounts does not constitute a health hazard but imparts an undesirable taste to drinking water. Copper occurs in copper plating wastes, copper pickling liquors. Copper compounds are toxic to fish and other aquatic life and microorganisms.
\end{abstract}

\section{Introduction:-}

Heavy metals have a great negative impact on the marine organisms. This effect ranges from behavioral and ecological to physiological changes which in turn reflect on economically, nutritionally and culturally important fish species. Heavy metals are soft but highly toxic as they compete for binding with essential metals $\mathbf{1 , 2}, \mathbf{8}, \mathbf{1 2}$, and consequently they interfere with sulphydryl groups that play an important role for normal function of enzymes and structural proteins. Effluents discharged from a human population differ in many characteristic constituents from that of the industries. Industrial effluents consists of a varied and large concentration of toxicants like heavy metal salts, unneutralised acids, organic matter, synthetic pesticides and also poisonous cyanides which play a vital role in spoiling the physico-chemical quality of water. There is a great possibility of these pollutants to percolate in the soil, possibly affect the ground waters, and reach up to the food chain of aquatic organisms leading to their death and affecting the health of human population which use this type of contaminated water ${ }^{4}$. Quality of water and the extent of pollution of lakes and rivers are determined from the health of the aquatic organisms surviving in it and the 
changes that has resulted in the environment ${ }^{6}$. Heavy metals are diluted and affected by various surface water components (carbonate, sulphate, organic compounds - humic, fulvic, amino acids) after entering natural water bodies which induces formation of insoluble salts or complexes. These salts and complexes are predicted to be not harmful to aquatic organisms ${ }^{3}$. Heavy metals are beneficial for living organisms under normal conditions but they tend to be toxic when their concentrations cross the established safe limits ${ }^{\mathbf{5 , 9}}$. Presently, heavy metal environmental pollution becomes an alarming signal and global issue for man, as it may cause deleterious and adverse effects on the existing natural ecological balance of the recipient environment ${ }^{13}$.

Metals in large water bodies cause accumulation biologically with the help of living entities alternatively from water or direct action. Basic metals are looked after by attaching to natural atoms to cause biochemical reactions where their capacity basically emphasis to impel or improve enzymatic movement ${ }^{\mathbf{1 1}}$. Vital metals at high fixations have a sublethal harmfulness impacts to a few creatures or deadly outcomes to others and likewise metals can have a twofold "poisonous" edge ${ }^{\mathbf{1 0}}$. Living life forms subjected to high metal focus accompany different components to counter potential danger. This lowered load of metals entering the living entities improve the quality of discharge or mixing and imparting metals to the tissue cells to make them nontoxic. This can be achieved by tagging the proteins like metallothioneins in cell inclusions. A few systems could be identified in a few living beings of furnishing vital metals for future needs ${ }^{7}$.

Materials And Methods:-

Processing of the fresh water fingerlings major carp Labeo rohita for study:-

Healthy fresh water fingerlings major carp Labeo rohita of both sexes were collected from the local fish farms. The fingerlings were transported in polythene bag containing $\mathrm{O}_{2}$ saturated water and brought to the aquarium nearly 125 to 160 fingerlings of Labeo rohita and were kept as stock. Normal fresh water, commercial fish food was given twice a day. Dissolved Oxygen level and $\mathrm{pH}$ of water was maintained in the laboratory to acclimatize the fish for 15 to 20 days. Different concentration of Copper was made by dissolving analytical grade Copper chloride in the fresh water. Amino acids were separated from the fish tissue with the help of centrifuge. For the qualitative and quantitative analysis of amino acids, ascending paper chromatographic techniques was used. 3 sets of different concn of Copper chloride $(01,02,03 \mathrm{ppm})$ were prepared for treatment.

\section{Preparation of sample:-}

Extraction of free a. a. from the fish tissues: Weighed tissues $(300 \mathrm{mg})$, were homogenized in glass homogenizer in $80 \%$ alcohol and was left for 24 hours at $0-4{ }^{\circ} \mathrm{C}$. The homogenous mixture was centrifuged after 24 hours and alcoholic supernatant was filtered and evaporated over water bath at $80^{\circ} \mathrm{C}$. The dried residue was extracted with 1 $\mathrm{ml}$ of $10 \%$ aqueous ethanol. These samples were used for chromatography for the determination of free amino acids

Solvent system:- $n$-Butanol: Glacial acetic acid: Distilled water - 4:1:5

Locating reagent:- $0.2 \%$ ninhydrin in acetone was used as locating reagent.

\section{Procedure:-}

Paper chromatographic technique is used for the detection of amino acids present in the fish muscle. Chromatograms were obtained. The amino acid location appeared as pinkish violet spots. The spots were circled with a pencil. The individual spots were cut out from the chromatograms and coloured spots from paper pieces in test tubes were extracted with $0.42 \%$ Sodium bicarbonate in $48 \%$ ethanol and kept undisturbed overnight. In the morning the test tubes were shaken and after the filter paper pieces settled down the coloured solutions were decanted in colour Imation tubes. The colour intensity of known and unknown spots of chromatograms was determined with the help of photo colorimeter using green filter. Then optical densities of amino acids were measured with the help of photo colorimeter.

\section{Results And Discussion:-}

The results denote that Copper chloride prominently affects the fish muscles as some amino acids are found to be reduced or even completely missing. This directly impairs the nutritive quality of the fish as they are of the main nutritive part of the fish containing high percentage of protein. Hence, the current study has been concentrated on presence of amino acids in the fish muscles including variation in its content. 
The results obtained after performing the experiments are represented in the following Table No.: 01. It represents the variations taking place in all the four amino acids that are present in fish Labeo rohita. The decreasing amount of the amino acids: Histidine, Proline, Glycine, Alanine, Methionine and Valine is shown in graph no.01, 02, 03, 04, 05 and 06 respectively.

Table1:- Change in optical density of different amino acids after exposure to various concentrations of Copper chloride.

\begin{tabular}{|c|c|c|c|c|}
\hline \multirow[t]{2}{*}{ Amino acids } & \multirow{2}{*}{$\begin{array}{c}\text { Copper } \\
\text { Concentration }\end{array}$} & \multicolumn{3}{|c|}{ Exposure time ( Days ) } \\
\hline & & 15 days & 30 days & 45 days \\
\hline$(01)$ & $(02)$ & $(03)$ & $(04)$ & $(05)$ \\
\hline \multirow{4}{*}{ Histidine } & Control & 0.035 & 0.035 & 0.035 \\
\hline & $1 \mathrm{ppm}$ & 0.034 & 0.033 & 0.032 \\
\hline & $2 \mathrm{ppm}$ & 0.032 & 0.030 & 0.026 \\
\hline & $3 \mathrm{ppm}$ & 0.030 & 0.014 & 0.009 \\
\hline \multirow{4}{*}{ Proline } & Control & 0.030 & 0.030 & 0.030 \\
\hline & $1 \mathrm{ppm}$ & 0.029 & 0.027 & 0.026 \\
\hline & $2 \mathrm{ppm}$ & 0.028 & 0.027 & 0.025 \\
\hline & $3 \mathrm{ppm}$ & 0.024 & 0.020 & 0.018 \\
\hline \multirow[t]{4}{*}{ Glycine } & Control & 0.037 & 0.037 & 0.037 \\
\hline & $1 \mathrm{ppm}$ & 0.035 & 0.033 & 0.032 \\
\hline & $2 \mathrm{ppm}$ & 0.033 & 0.030 & 0.026 \\
\hline & 3 ppm & 0.029 & 0.025 & 0.020 \\
\hline \multirow[t]{4}{*}{ Alanine } & Control & 0.021 & 0.021 & 0.021 \\
\hline & $1 \mathrm{ppm}$ & 0.020 & 0.018 & 0.017 \\
\hline & $2 \mathrm{ppm}$ & 0.018 & 0.016 & 0.013 \\
\hline & $3 \mathrm{ppm}$ & 0.016 & 0.014 & 0.011 \\
\hline \multirow[t]{4}{*}{ Methionine } & Control & 0.029 & 0.029 & 0.029 \\
\hline & $1 \mathrm{ppm}$ & 0.026 & 0.024 & 0.023 \\
\hline & $2 \mathrm{ppm}$ & 0.025 & 0.022 & 0.019 \\
\hline & $3 \mathrm{ppm}$ & 0.023 & 0.021 & 0.013 \\
\hline \multirow[t]{4}{*}{ Valine } & Control & 0.025 & 0.025 & 0.025 \\
\hline & $1 \mathrm{ppm}$ & 0.024 & 0.022 & 0.020 \\
\hline & $2 \mathrm{ppm}$ & 0.022 & 0.021 & 0.018 \\
\hline & 3 ppm & 0.021 & 0.014 & 0.010 \\
\hline
\end{tabular}

Graph 01:-

Graph showing optical density change of Histidine after exposure to various concentration of Copper Chloride.

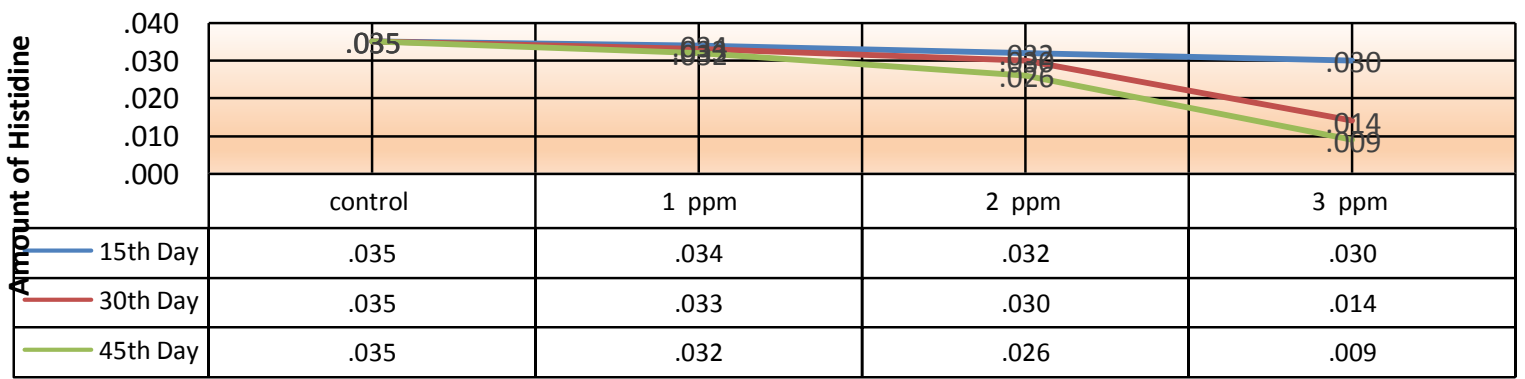


Graph 02:-

Graph showing optical density change of Proline after exposure to various concentration of Copper Chloride.

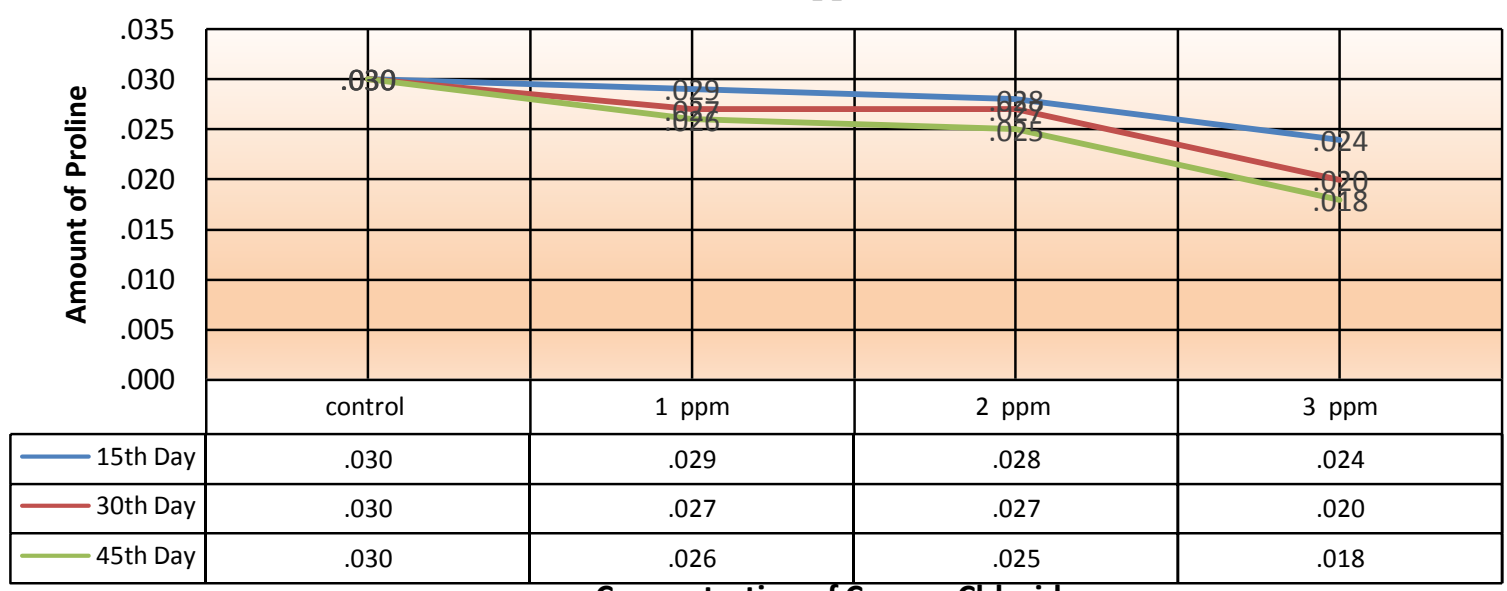

Concentration of Copper Chloride

Graph 03:-

Graph showing optical density change of Glycine after exposure to various concentration of Copper Chloride.

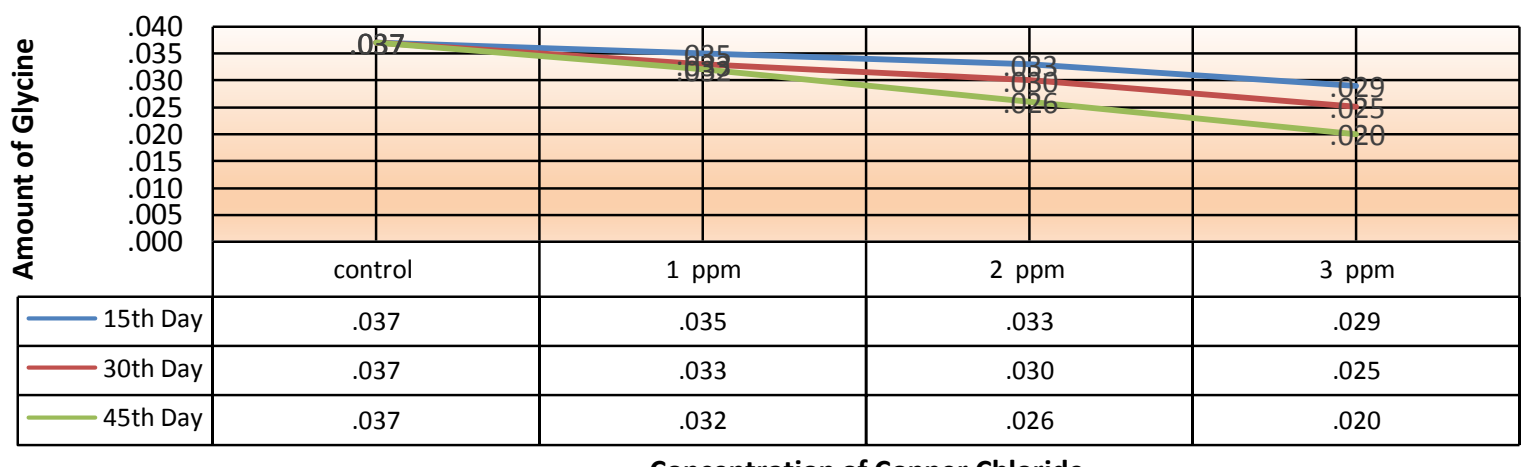

Concentration of Copper Chloride

Graph 04:-

Graph showing optical density change of Alanine after exposure to various concentration of Copper Chloride.

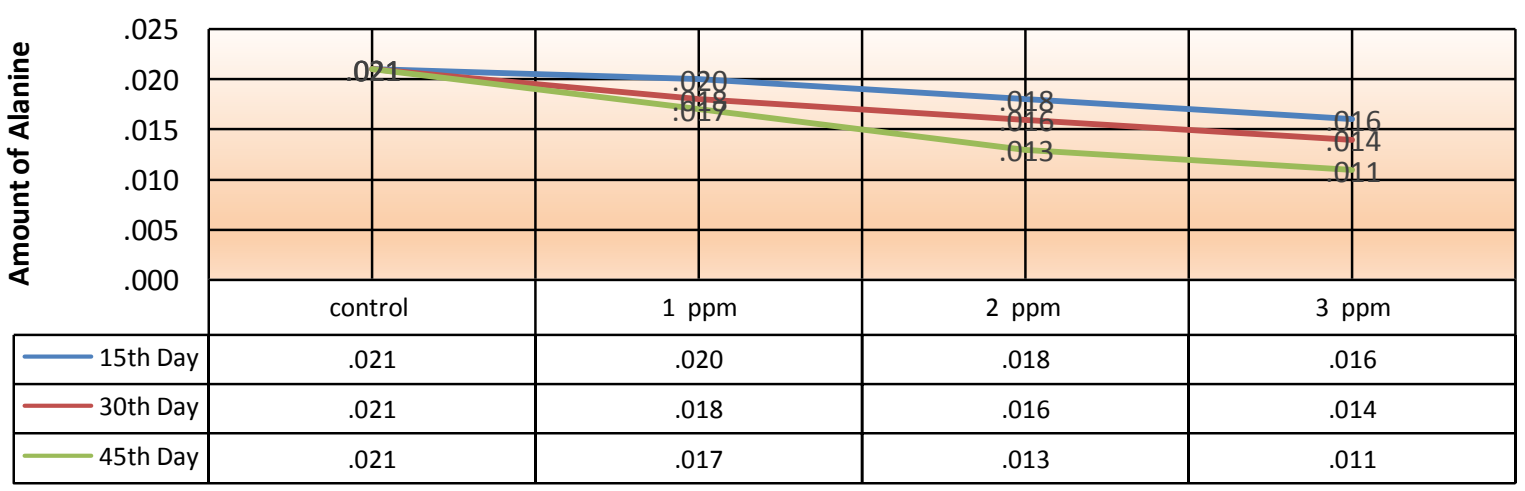

Concentration of Copper Chloride 
Graph 05:-

Graph showing optical density change of Methionine after exposure to various concentration of Copper Chloride.

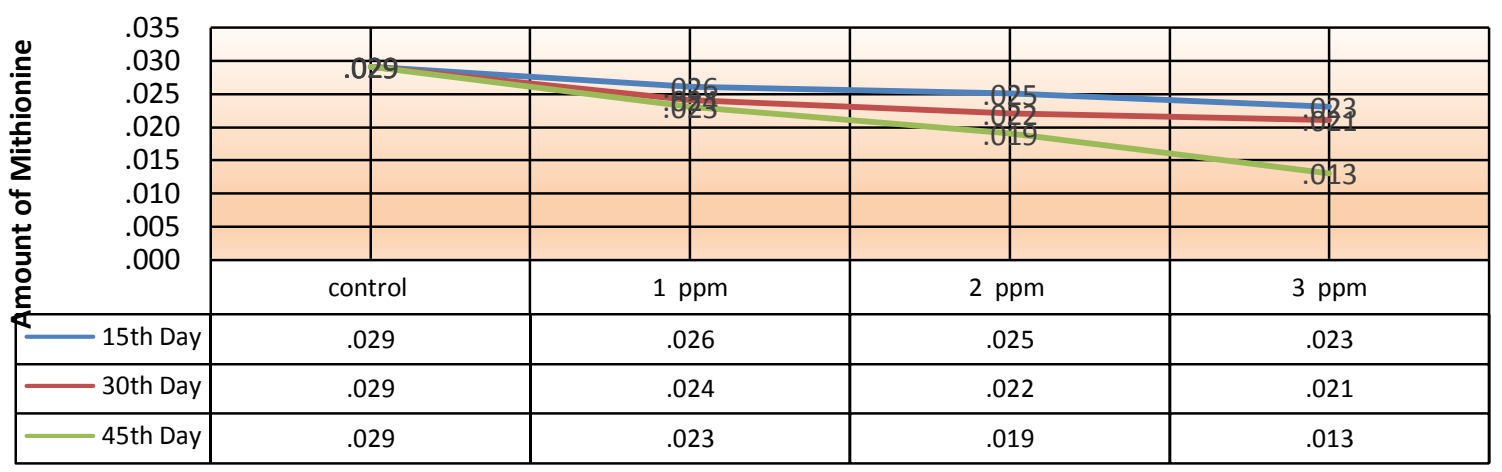

Concentration of Copper Chloride

Graph 06:-

Graph showing optical density change of Valine after exposure to various concentration of Copper Chloride.

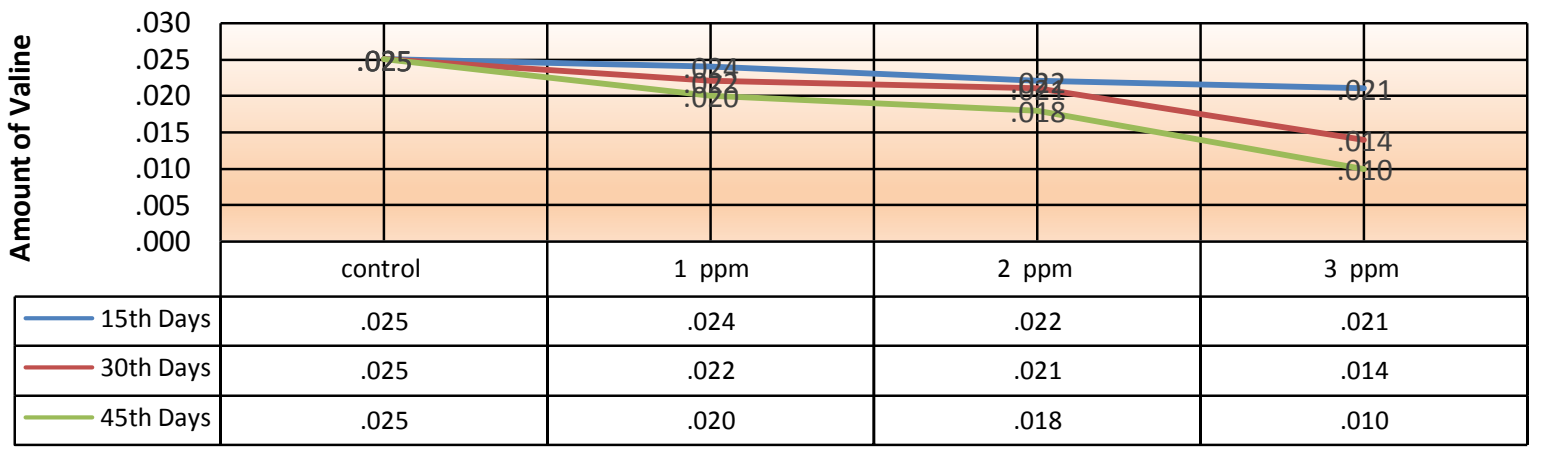

Concentration of Copper Chloride

Histidine in normal fish was up to 0.035 O.D., it is reduced to 0.033 on 30 and 0.032 on exposure of 45 days in 1 ppm Copper chloride media exposed fish. As concentration increased there was drastic change in Optical Density in 2 and 3 ppm. on 30 and 45 days.(Graph 1).

Proline has normally shown 0.030 Optical Density. But even during longer days and higher concentration it was traceable only with reduction in Optical Density readings (Graph 2).

Glycine has normally shown 0.037 Optical Density it went down to 0.026 and 0.20 Optical Density on 45 days in 2 and 3 ppm irrespectively (Graph 3).

Alanine even in control fish has shown 0.021 on 15,30 and 45 days. In 2 ppm it was 0.016 and 0.013 Optical Density on 30 and 45 days. But when fish were exposed to $3 \mathrm{ppm}$ for 30 days there was great reduction up to 0.014 Optical Density and on 45 days the reduction was up to 0.011 Optical Density of amino acids (Graph 4).

Methionine normally ranged at 0.029 Optical Density, was depleted up to 0.013 on 45 days in 3 ppm (Graph 5).

Valine normally shows 0.025 Optical Density but its reduced Optical Density was 0.024 to 0.020 on $15-30$ and 45 days in $1 \mathrm{ppm}$. In case of $2 \mathrm{ppm}$ it ranged from.0.22 to 0.18 Optical Density on 15 and 45 days of exposure. While in $3 \mathrm{ppm}$ on 30 days presence of Valine was very low, the Optical Density was 0.014 and was 0.10 on 45 days (Graph 6). 


\section{Conclusion:-}

Protein deficiency in a human body leads to a number of health related problems, including reduction of chondroblastic and osteoblastic activity. This leads to an acute situation where the normal growth and formation of the bones and the cartilage gets hampered, which finally results in irreparable deformities in the body of the growing children, and also in adults. Fish is the staple food of the people of South Gujarat region. Hence it is a matter of utmost importance to study and constantly monitor the various heavy metal pollutants in water in the Southern region of the state of Gujarat.

\section{References:-}

1. Allen P (1995). Accumulation profiles of cadmium and their modification with mercury and lead in the edible tissues of Oreochromis aureus. Fresh Environ Bull 2: 745-751.

2. Chattopadhyay S, Anam K, Aditya A K (1995). Time dependent distribution of heavy metal in different tissues of Labeo rohita. J Freshwat Biol, 7: 203-205.

3. Eisler. R (1998). Copper Hazards to Fish. Wildlife and Invertebrates: A Synoptic Review. Biological Science Repot I 'SGSBRD’BRS-1997-0002.

4. Farkas A, Salanki J, Specziar A (2002). Relation between growth and heavy metal concentration in organs of bream, Abramis brama L, population lake Balaton. Arch. Environ. Contam. Toxicol. 43: 236-243.

5. Farombi EO, Adelowo OA, Ajimoko RK (2007). Biomarkers of oxidative stress and heavy metal levels as indicators of environmental pollution in African Cat Fish (Clarias gariepinus) from Nigeria Ogun River, Int. J. Environ. Res. Pub. Health, 4: 158-165.

6. Kock G, Triendl M, Hofer R (1996). Seasonal patterns of metal accumulation in Artic char (Salvelinus alpinus) from an oligotrophic Alpine lake related to temperature. Can. J. Fish. Aquat. Sci. 53: 780-786.

7. Kotze P, Du Preez HH, Van Vuren JHJ: (1999). Bioaccumulation of copper and zinc in Orechromis mossambicus and Clarias gariepinus, from the Olifants River, Mpumalanga, South Africa. Water SA, 25(1): 99110.

8. Kumar LCA, Vincent S, Ambrose T (1994). Uptake and persistence of the heavy metal cadmium in tissues of the fresh water fish Cyprinus carpio. Poll Res 13: 361-364.

9. Patel J M, Bahadur A (2011). Histopathological Manifestations of Sub Lethal toxicity of Copper Ions in Catla catla. Am. Eur. J. Toxicol. Sci. 3(1): 01-05.

10. Rainbow PS. Trace metal bioaccumulation: (2007). Models, metabolic availability and toxicity. Review. Envoron Int 33: 576-582.

11. Regan L (1993). The design of metal-binding in proteins. Review. Annu Rev Biophys Biomol Structure, 22: 257-281.

12. Sastry KV, Shukla V (1994). Influence of protective agents in the toxicity of cadmium to a fresh water fish (Channa punctatus) Bull Environ Contam Toxicol 53: 711-717.

13. Vutukuru SS (2005). Acute effects of Hexavalent chromium on survival, oxygen consumption, hematological parameters and some biochemical profiles of the Indian major carp, Labeo rohita, International Journal of Environmental Research and Public Health, 2(3): 456-462. 